\title{
Chapter 17 \\ Potential Impact of Climate Change on Alpine Habitats from Bucegi Natural Park, Romania
}

\author{
Anca Sârbu, Paulina Anastasiu, and Daniela Smarandache
}

\subsection{Climate Change and Protected Areas}

The predicted increase in global temperature (annual average $1.1-6.4{ }^{\circ} \mathrm{C}$ ) and the changes in the amount and distribution of precipitation (IPCC 2007), represent a significant challenge for the plants and habitats within and outside of protected areas (Andrade et al. 2010). Some studies anticipate a reduction of $58 \%$ of plant and animal diversity in the protected areas of Europe by the end of 2080 (Araújo et al. 2011). Alpine plants within and outside protected areas, are expected to experience significant impacts as a results of climate change, during this century (Erschbamer et al. 2009). According to Theurillat et al. (1998), high mountains such as the Alps can be particularly vulnerable to climate change and the impact of the combined effects of human activity and climate change are more and more visible (Fischlin et al. 2007). In this context, the concept of adaptative management of nature reserves can become a potential way to proactively respond to climate change influences (Fazey et al. 2009).

\subsection{Area of Study}

The focus of this chapter is the identification of the threats that concern alpine habitats, of the way in which these habitats might react to such threats and of those aspects that could be scientifically significant in supporting the selection of the adequate management practices. For the purpose of this study, Bucegi Natural Park in Romania was taken as a case study and the Festuca supina Schur grassland (Natura 2000 code 6150-Siliceous alpine and boreal grasslands), which represent

\footnotetext{
A. Sârbu $(\bowtie) \cdot$ P. Anastasiu • D. Smarandache

Department of Botany and Microbiology, University of Bucharest, Aleea Portocalelor 1-3, Sector 5, 060101 Bucureşti, Romania

e-mail: anchusa24@yahoo.com; anastasiup@yahoo.com; d.smarandache@yahoo.com
} 


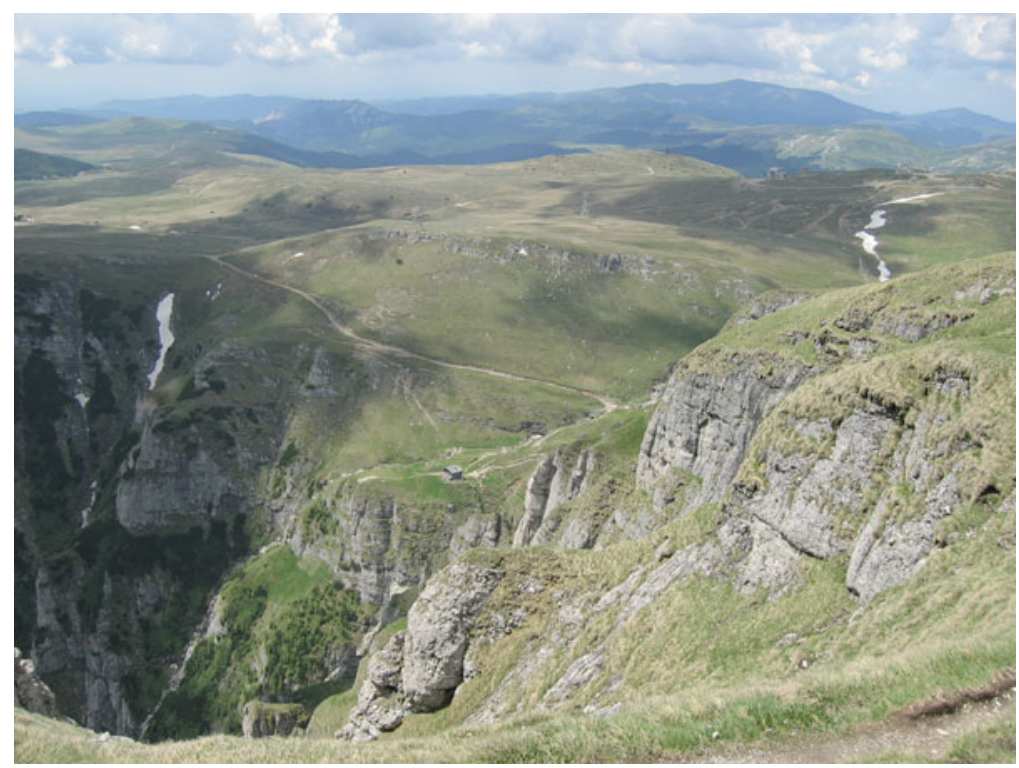

Fig. 17.1 Natural Park Bucegi, alpine grasslands on the plateau of the Bucegi mountains (Photo: Anca Sârbu)

$26 \%$ of its alpine grasslands (Puşcaru et al. 1956) and are the most widespread type of habitat in the alpine area (Administraţia Parcului Natural Bucegi 2011) was used as an example.

Bucegi Natural Park $(32,497.6$ ha) is located on the South-Eastern extremity of the Romanian Carpathians, lying between 800 and $2,507 \mathrm{~m}$ in altitude (Administraţia Parcului Natural Bucegi 2011), its normal climate is cold and humid, with temperatures well below zero during winter, long periods of snow and frost, violent winds especially on peaks, frequent fog especially in the alpine area, and heavy rainfall (Administraţia Parcului Natural Bucegi 2011) (Fig. 17.1).

The Park belongs to the Natura 2000 Bucegi Site which hosts 24 types of Natura 2000 habitats of the following categories: shrubs, natural meadows, hydrophilic vegetation, deciduous forests, coniferous and mixed forests. About $30 \%$ of all taxa known in the Romanian higher plant flora are present in the Park including 59 endemic plants (Administraţia Parcului Natural Bucegi 2011) and four plants recorded in Annex II of the Habitats Directive (Council Directive 92/43/EEC 1992), as well as a rich bryoflora and many species of fungi and lichens. The land use includes: national forestry fund (62\%), pastures and grasslands (32\%), rocky habitats and Pinus mugo formations (4.9\%), water surfaces $(0.4 \%)$, quarries and touristic infrastructure $(0.7 \%$ ) (Administraţia Parcului Natural Bucegi 2011). 


\subsection{Data Collection in Bucegi Natural Park}

The identification of the effects of climate change and of the different potential threats affecting the protected area was based on the results of a survey conducted in 2010, addressed to 97 subjects (landowners, land users and significant stakeholders) involved in the management of Bucegi Natural Park.

Estimation of the potential vulnerability of Festuca supina (Ciocârlan 2009) grasslands to the potential impacts of climate change was based on analysis of 16 plots of $25 \mathrm{~m}^{2}$, identified on the plateau of the mountain between 2010 and 2012. All 16 plots of habitat type 6150 were located at an altitude between 1,900 and $2,300 \mathrm{~m}$, with low temperatures (annual average temperature between -2.5 and $\left.3{ }^{\circ} \mathrm{C}\right)$, sufficient humidity $(1,100-1,400 \mathrm{~mm} /$ year) and a minimum snow coverage of 200 days per year (Puşcaru et al. 1956; Doniţă et al. 2005).

The following parameters were used: species richness, species abundancedominance and species potential sensitivity. The species conservation value was defined according to the Red List of Higher Plants of Romania (Oltean et al. 1994) and to the Annex II of the Habitats Directive. Species nomenclature is in accordance with The Plant List (2010).

The assessment of the potential sensitivity of species to climate changes used the following criteria: the life span, biological form, the requirements in terms of humidity, heat and nutrients, evaluated according to the groups of biological forms and to scales for moisture, heat and nutrient requirement, used in determining the ecology of species in Romania (Popescu and Sanda 1998; Ciocârlan 2009).

\subsection{Potential Pressures and Consequences of Climate Change in Bucegi Natural Park}

The results of the survey addressed to owners, users and stakeholders involved in the management of Bucegi Natural Park revealed four categories of climate change pressures, associated with either the phenomenon of global warming or with rainfall imbalances or severe weather and seasonal disturbances: increase in temperature, decrease in rainfall, seasonal changes in precipitation and temperature and increase of extreme weather phenomena. Their effects can threat directly and indirectly plants diversity and habitats quality (Fig. 17.2).

The habitat type 6150, which was considered in this study comprises of alpine grasslands of Festuca supina, which form dense vegetation, composed of many plant taxa (122-130), widely dominated by Festuca supina (65-85\%), with 10-22 \% Agrostis rupestris All. and Potentila ternata Freyn (Fig. 17.3). It is an oligotherm habitat, a glacial relict, which shelters 26 taxa with conservation value listed in the Red List of Higher Plants of Romania (Oltean et al. 1994).

The dominant species are perennial, and dependent on moderate humidity (mesophilic), the presence of snow (hemicryptophyte and chamaephyte) and low 


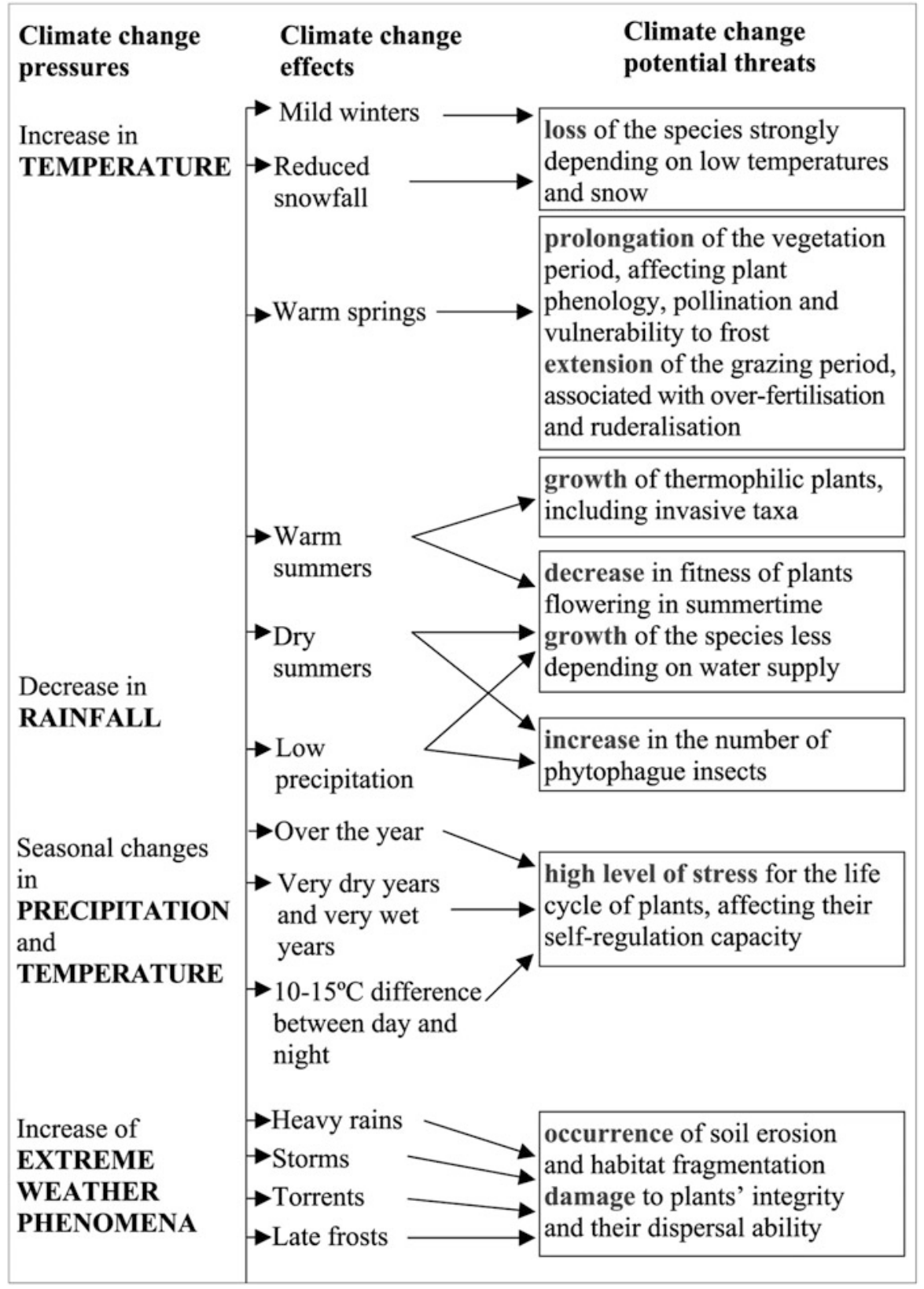

Fig. 17.2 Potential climate change effects and induced threats on the alpine plants and habitats from Bucegi Natural Park 


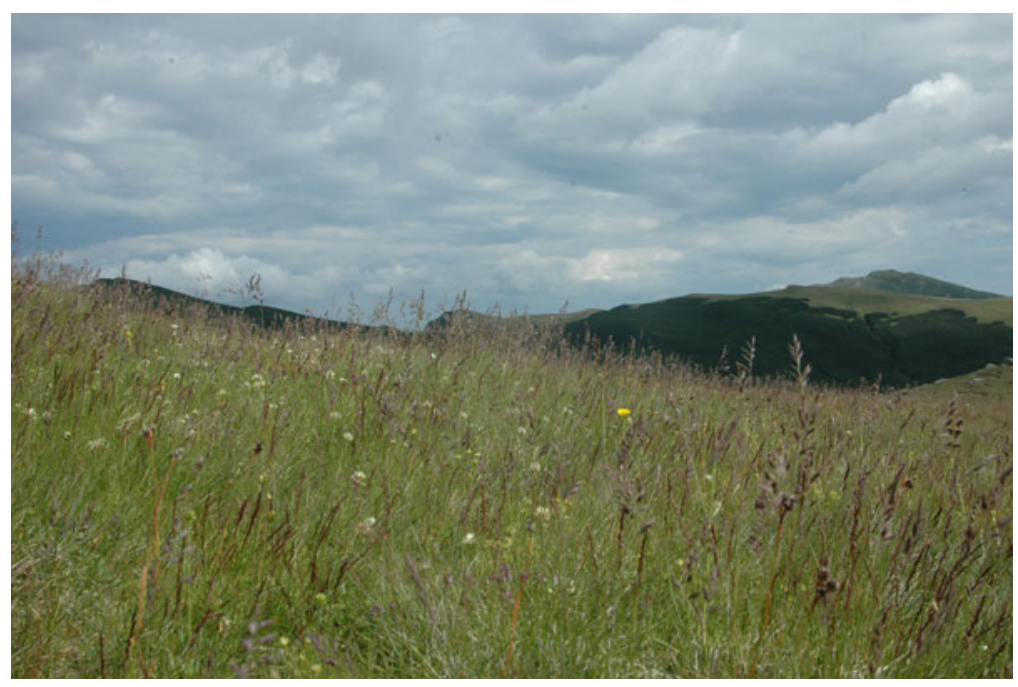

Fig. 17.3 Natural Park Bucegi, Festuca supina grassland (Natura 2000 code 6150) (Photo: Anca Sârbu)

temperatures (hekistothermophytes and psychrothermophytes). They are oligotrophic plants. The accompanying species are $89 \%$ hemicryptophyte and chamaephyte. Seventy percentage of the identified species are dependent either on humidity (mesophytes and mesohydrophyte) or on low temperatures (hekistothermophytes, psychrothermophytes and microthermophytes), and $40 \%$ are oligotrophic. About $52 \%$ of the plant species of Festuca supina grasslands, include the dominant species, twelve rare plants and three endemics Achillea oxyloba subsp. schurii (Sch.Bip.) Heimerl, Androsace villosa var. arachnoidea (Schott, Nyman \& Kotschy) R. Knuth, Dianthus glacialis subsp. gelidus (Schott, Nyman \& Kotschy) Tutin, require both low temperatures and moisture for an adequate growth.

The analysis of the species identified in habitat type 6150 revealed the presence of some eurithermophyte and mesothermophyte, and some eutrophic species, which are not normally found in this type of habitat (Doniţă et al. 2005; Gafta and Mountford 2008). Some of these might have migrated from neighbouring habitats, at a lower altitude. We mention here Deschampsia caespitosa (L.) P. Beauv., Gnaphalium sylvaticum L., Cardamine pratensis L., as well as Nardus stricta L., which is a dominant and characteristic species for the habitat 6230* (Species - rich Nardus grasslands). This habitat develops at lower altitudes (800-2,070 m) and in climate conditions characterised by average annual temperatures of between 1.5 and $6.0{ }^{\circ} \mathrm{C}$ (Mountford et al. 2008).

The existence of some eutrophic and mesothrophic species (Biscutella laevigata L., Alyssum repens Baumg., Ranunculus repens L. s.o.) can be explained by the tendency towards eutrophication of these grasslands, which is in general, a process associated with grazing activities (Doniţă et al. 2005). 


\subsection{Climate Change Threats and Worrying Aspects}

One of the consequences of climate change that alpine plants and habitats will have to face is the potential occurrence of milder winters with less snow. The length and depth of snow cover, correlated with low temperature is considered as a key climatic element in alpine areas (Ozenda and Borel 1991) and the plants from the alpine level, such as the hekistothermophytes and the psychrothermophytes from Bucegi mountains, are sensitive to these factors.

At the same time, a reduction in the duration of snow coverage and amount of snowfall will affect the regeneration of plants from the high elevation of Bucegi mountains, which depend on vernalisation. According to Ozenda and Borel (1991), the species living in snow beds will be the most vulnerable to warming.

Plant species can respond to changes of the climatic conditions in different ways: genetic adaptation, species extinction, biological invasion (Huntley 1991). Up to now we have minimal empirical evidence of how the alpine plants from Bucegi mountains will react to environmental changes.

However, it is worrying that the dominant species of Festuca supina grasslands and also the majority of the other present species including rare and endemic plants are mostly hemicryptophyte and chamaephyte, and microthermic dependent.

Another worrying aspect is related to the upward migration process of plants which can produce changes in the vegetation from the existing habitats and can affect the cryophilous plants. An upward migration of some species from lower altitudes seeking climatic conditions suitable for their life functions was also observed for the habitat type 6150 from Bucegi Natural Park. This type of response to the effects of climate change has also been reported in the Alps (Theurillat et al. 1998; Pauli et al. 2003).

The alpine habitats from Bucegi National Park are subject to various influences of human activity. As far as grasslands are concerned, grazing has a particularly significant impact and should be taken into account because both the dominant plants in the studied habitat type, and the associated species are oligotrophic and sensitive to eutrophication. According the evaluation from the Management Plan of the Bucegi Natural Park, chapter IV (Administraţia Parcului Natural Bucegi 2011), pastures and meadows in Bucegi Natural Park have different amounts of livestock that often exceed the optimum number of units for grazing land, set at $0.30 \mathrm{LUs} / \mathrm{ha}$. Intense grazing by various livestock (sheep, horses, goats, cows) is a source of intense eutrophication and of soil quality degradation, associated with ruderalisation (Doniţă et al. 2005), a process that can affects the integrity of Festuca supina grasslands. The emergence of early and warm springs, allows the prolonging of the grazing period and for the grazing to start at an earlier time, affecting the regeneration and breeding capacity of spring plants and increasing soil nutrients.

In these circumstances, the question is: "How will alpine habitats from Bucegi mountains respond to climate change?" Certainly each habitat react rather individually, but the current structure of the plant communities and the ecological spectrum of the component species may offer some indication. In an environment 
showing evidence of a change in climate and by limited options for intervention, alpine plants are very likely to become a disadvantaged category.

However, the reduction of the non-climatic stress such as grazing (extension in time, diversity of livestock, livestock overload), motorised tourism and the development of the tourism infrastructure, can be an alternative measure to buffer as much as possible the impact that climate change has or might have on the alpine plants and habitats from Bucegi Natural Park.

According to Theurillat and Guisan (2001), the perpetuation of traditional landuse, without intensification can be considered a key factor to offset climate change over the following decades, especially for extensively used ecosystems such as subalpine and alpine grasslands.

\subsection{Conclusions}

Significant climate change pressures such as increasing temperatures, decreasing precipitation, seasonal changes and extreme phenomena, affect the habitats of the Bucegi Natural Park and we can expect the loss of those plants which will no longer have adequate conditions for survival and a gradual change of their habitats. The analyses of the structure of the plant communities and of their ecological spectrum offer some indication of the potential future tendencies in the habitats' changes. In this regard, the selected Natura 2000 habitat type 6150, well represented in the Carpathian Mountains, populated by plant species strongly depending on low temperatures and the presence of snow can be considered as potentially vulnerable.

A way to buffer as much as possible the effects of climate change on alpine habitats, could be linked to efforts to decrease or limit the impact of human activities, thus avoiding, or at least diminishing, the cumulative effects of climatic and non-climatic stress.

Acknowledgements The presented activities and results were developed in the framework of the HABIT-CHANGE project: Adaptive management of climate induced changes of habitats diversity in protected areas, implemented through the CENTRAL EUROPE Programme co-financed by the ERDF.

Open Access This chapter is distributed under the terms of the Creative Commons Attribution Noncommercial License, which permits any noncommercial use, distribution, and reproduction in any medium, provided the original author(s) and source are credited.

\section{References}

Administraţia Parcului Natural Bucegi. (2011). Plan management. Retrieved June 12, 2012, from www.bucegipark.ro

Andrade, P. A., Herrera, F. B., \& Cazzola, G. R. (Eds.). (2010). Building resilience to climate change: Ecosystem-based adaptation and lessons from the field. Gland: IUCN. 
Araújo, M. B., Alagador, D., Cabeza, M., Nogués-Bravo, D., \& Thuiller, W. (2011). Climate change threatens European conservation areas. Ecology Letters, 14(5), 484-492.

Ciocârlan, V. (2009). Flora Ilustrată a României (Pteridophyta et Spermatophyta, Vol. 3). Bucureşti: Editura Ceres.

Council Directive 92/43/EEC of 21 May 1992 on conservation of natural habitats and of wild fauna and flora (Habitat Directive). Retrieved June 20, 2012, from http://eur-lex.europa.eu/ LexUriServ/LexUriServ.do?uri=DD: 15:02:31992L0043:RO:PDF

Doniţă, N., Popescu, A., Paucă-Comănescu, M., Mihăilescu, S., \& Biriş, I. A. (2005). Habitatele din România. Bucureşti: Editura Tehnică Silvică.

Erschbamer, B., Kiebacher, T., Mallaun, M., \& Unterluggauer, P. (2009). Short-term signals of climate change along an altitudinal gradient in the South Alps. Plant Ecology, 202, 79-89.

Fazey, I., Gamarra, J., Fischer, J., Reed, M., Stringer, L., \& Mike, C. (2009). Adaptation strategies for reducing vulnerability to future environmental change. Frontiers in Ecology and the Environment, 8(8), 414-422.

Fischlin, A., Midgley, G. F., Price, J. T., Leemans, R., Gopal, B., Turley, C., Rounsevell, M. D. A., Dube, O. P., Tarazona, J., \& Velichko, A. A. (2007). Ecosystems, their properties, goods, and services. In M. L. Parry, O. F. Canziani, J. P. Palutikof, P. J. van der Linden, \& C. E. Hanson (Eds.), Climate change 2007: Impacts, adaptation and vulnerability (Contribution of working group II to the fourth assessment report of the Intergovernmental Panel on Climate Change, pp. 211-272). Cambridge: Cambridge University Press.

Gafta, D., \& Mountford, O. (coord.). (2008). Manual de interpretare a habitatelor Natura 2000 din România. Cluj-Napoca: Editura Rosprint.

Huntley, B. (1991). How plants respond to climate change: Migration rates, individualism and the consequences for plant communities. Annals of Botany, 67(Suppl. 1), 15-22.

IPCC [Intergovernmental Panel on Climate Change]. (2007). Summary for policy makers. In M. L. Parry, O. F. Canziani, J. P. Palutikof, P. J. van der Linden, \& C. E. Hanson (Eds.), Climate change 2007: Impacts, adaptation and vulnerability (Contribution of working group II to the fourth assessment report of the Intergovernmental Panel on Climate Change (IPCC)). Cambridge: Cambridge University Press.

Mountford, O., Gafta, D., Anastasiu, P., Bărbos, M., Nicolin, A., Niculescu, M., \& Oprea, A. (2008). Natura 2000 in Romania. Habitat fact sheets. Bucureşti: Ministry of Environment and Sustainable Development.

Oltean, M., Negrean, G., Popescu, A., Roman, N., Dihoru, G., Sanda, V., \& Mihăilescu, S. (1994). Lista roşie a plantelor superioare din România. In M. Oltean (Coord.). Studii, sinteze, documentaţii de ecologie, Academia Română, Institutul de Biologie 1, 1-52.

Ozenda, P., \& Borel, J.-L. (1991). Les conséquences écologiques possibles des changements climatiques dans l'Arc alpin, Rapport FUTURALP 1 (p. 49). Chambéry: Centre International pour l'Environnement Alpin (ICALPE).

Pauli, H., Gottfried, M., \& Grabherr, G. (2003). Effects of climate change on the alpine and nival vegetation of the Alps. Journal Mountain Ecology, 7(Suppl), 9-12.

Popescu, A., \& Sanda, V. (1998). Conspectul florei cormofitelor spontane din România. Acta Botanica Horti Bucurestiensis, 3-336.

Puşcaru, D., Puşcaru-Soroceanu, E., Paucă, A., Şerbănescu, I., Beldie, A., Ştefureac, T., Cernescu, N., Saghin, F., Creţu, V., Lupan, L., \& Taşcenco, V. (1956). Păşunile alpine din Munţii Bucegi. Bucureşti: Editura Academiei Române.

The Plant List. (2010). Version 1. [Online]. Retrieved June 27, 2012, from http://www.theplantlist.org/ Theurillat, J.-P., \& Guisan, A. (2001). Potential impact of climate change on vegetation in the European Alp: E review. Climatic Change, 50, 77-109.

Theurillat, J.-P., Felber, F., Geissler, P., Gobat, J.-M., Fierz, M., Fischlin, A., Küpfer, P., Schlüssel, A., Velutti, C., \& Zhao, G.-F. (1998). Sensitivity of plant and soils ecosystems of the Alps to climate change. In P. Cebon, U. Dahinden, H. C. Davies, D. Imboden, \& C. C. Jaeger (Eds.), Views from the Alps: Regional perspectives on climate change (pp. 225-308). Cambridge: MIT Press. 